\title{
Prevalence of Antibiotic Resistant Bacteria on Tomato Surfaces and Effectiveness of Disinfectants in Reducing the Microbial Load
}

\author{
Fauzia Ahmed Rupa ${ }^{1}$, Munawar Sultana ${ }^{1}$, Yasuhiro Inatsu ${ }^{2}$, Md. Latiful Bari ${ }^{3}$ and Md. Anwar Hossain ${ }^{1}$ \\ 1. Department of Microbiology, University of Dhaka, Dhaka 1000, Bangladesh \\ 2. Food Hygiene Research Laboratory, National Food Research Institute, 2-1-12, Kannondai, Tsukuba-shi, Ibaraki 305-8642, Japan \\ 3. Food Analysis and Research Laboratory, Center for Advanced Research in Sciences, University of Dhaka, Dhaka 1000, \\ Bangladesh
}

Received: February 8, 2012 / Published: May 20, 2012.

\begin{abstract}
This study was conducted to isolate and identify antibiotic resistant bacteria in fresh tomato sold in three different local markets of Dhaka city. On an average $>5.0 \mathrm{log}$ CFU/g of natural microbial populations and coliform bacteria was present in the samples. Prevalence of Salmonella spp., E. coli, Listeria spp., and Yersinia spp., were recorded through cultivation dependent assay of tomato samples of different markets. Almost all of the isolates were uniformly resistant to rifampicin, erythromycin, clindamycin and oxacillin (100\%), vancomycin (93\%), amoxicillin (87\%), whereas $60 \%$ of the isolates were found to be resistant to ampicillin and cephalexin. Antibiotic sensitivity test of the presumptive E. coli and Salmonella spp. and corresponding plasmid profiling indicated a correlation of plasmid mediated multidrug resistance (MDR) of these environmental bacteria. Washing with sanitizing agents such as acidified sodium chlorite (ASC) and $200 \mathrm{ppm}$ chlorinated water was able to reduce $\leq 2.0 \mathrm{log}$ CFU/g of natural microflora and coliform bacteria. In contrast, ASC was able to reduce $\leq 2.0 \mathrm{log} \mathrm{CFU} / \mathrm{g}$ of other food borne pathogens and, chlorinated water was able to reduce up to undetectable level. Therefore, washing of tomato with $200 \mathrm{ppm}$ chlorinated water could be useful in reducing the pathogen populations on tomatoes.
\end{abstract}

Key words: Antibiotic resistant bacteria, acidified sodium chlorite, chlorinated water, E. coli O157:H7, salmonella spp., tomato.

\section{Introduction}

In recent years, there has been an increase consumption of fresh tomatoes in most countries as a well-known source of lycopene, essential nutrients as vitamins $\mathrm{A}, \mathrm{B}$ and $\mathrm{C}$ and antioxidants, minerals as potassium, iron and calcium (health 24 website). One medium ripe tomato can provide up to $40 \%$ of the recommended daily allowance of vitamin $\mathrm{C}$ and $20 \%$ of vitamin A. Tomato is used as either a fresh fruit, sun-dried or processed into sauce, juice, pastes [1] etc.. Fresh tomatoes have repeatedly been associated with

Corresponding author: Md. Anwar Hossain, professor and chairman, research fields: microbiology, food microbiology. E-mail: hossaina@du.ac.bd. major outbreaks of salmonellosis; multistate outbreaks occurring in 1990, 1993, 1998, 2002, and 2004 were responsible for more than 1,300 cases [2-4]. During growing and harvesting, tomatoes are frequently in contact with soil, insects, animals or humans [5]. Such products are often eaten raw or with minimal processing. It contaminated with microbial pathogens, they may pose a health hazard to consumers. With recognizing the potential for $E$. coli contamination of leafy green vegetables, the FDA and the food industry have raised concerns on the continuing outbreaks in the lettuce and tomato industries [6].

Washing of produce with tap water may remove some soil and other debris, but it cannot remove 
microorganisms completely [7]. Chlorine is most often used as a disinfectant for fresh produce in both immersing and spraying water at packinghouse operations and can reduce the presence of pathogenic microorganisms [8]. Acidified sodium chlorite (ASC), an antimicrobial agent, is permitted by the FDA for use in the water applied to processed fruits and vegetables at concentrations of 500 to $1,200 \mathrm{ppm}$ and pH 2.3 to 2.9 by spraying or dipping, followed by a potable water rinse and a 24 -hour waiting period prior to consumption; with leafy vegetables, only application by dipping is permitted [9].

Therefore, the aims of this study were: (1) to evaluate the total bacterial load, (2) to isolate and identify antibiotic resistant bacteria in fresh tomato; (3) to examine their resistant pattern and plasmid profile; and (4) also to see the effectiveness of acidified sodium chlorite (ASC) and chlorinated water (200 $\mathrm{ppm}$ ) in reducing these resistance bacteria and other microorganisms on tomato.

\section{Materials and Methods}

\subsection{Tomatoes Collection}

Commercial tomatoes were purchased from Ananda market, Mirpur market and Jatrabari market of Dhaka city, Bangladesh and were processed within $24 \mathrm{~h}$ of collection. Two kilograms of tomatoes from each market were collected in sterilized ziploc bag, and transported to the laboratory in a cool box and were processed within $24 \mathrm{~h}$ of collection. Each tomato weighed $40.0 \pm 0.5 \mathrm{~g}$ as measured by an electric balance (Shimadzu Corporation, Tokyo, Japan). Injured or dirty tomatoes were discarded.

\subsection{Washing Solution and Sample Washing}

ASC and chlorine water were used as washing solutions and were prepared immediately prior to application. The final concentration of acidified sodium chlorite solutions was adjusted to $0.5 \mathrm{~g} / \mathrm{L}$ of sodium chlorite and $1 \mathrm{~g} / \mathrm{L}$ of citric acid. The chlorine solution was prepared using sodium hypochlorite
(Wako Chemical Co. Ltd, Osaka, Japan) solution to distilled water ( $\mathrm{vol} / \mathrm{vol})$, and concentration was adjusted to $200 \mathrm{ppm}$. Distilled water (DW) was used as a control. In each experimental condition, one tomato (ca. $40 \mathrm{~g}$ ) was washed with $250 \mathrm{~mL}$ of the washing solution in a sterile beaker $(1 \mathrm{~L})$. Washing was carried out for $2 \mathrm{~min}$ at room temperature with gentle agitation by using a glass rod. After washing, the solution was decanted, and tomatoes were rinsed with $250 \mathrm{~mL}$ of distilled water. Then the tomatoes were placed on a sterile perforated tray to drain off the excessive water and placed in laminar flow bio-safety cabinet to facilitate drying for 2 hours.

\subsection{Sample Processing and Microbiological Analysis}

After washing and drying, the tomatoes were aseptically cut into small pieces and ten grams of sliced tomato were placed in a stomacher bag with 90 $\mathrm{mL}$ of sterile saline water. Diluted and undiluted samples were surface plated on both selective and nonselective agar medium. Tryptic soy agar (TSA; Oxoid) was used as a nonselective medium for determination of viable cells number. Coliform agar; sorbitol macconkey agar (SMAC) supplemented with cefixime $(0.05 \mathrm{mg} / \mathrm{liter})$ and potassium tellurite $(2.5$ $\mathrm{mg} /$ liter) (CT-selective supplement, Oxoid); bismuth sulfite agar (BSA; Oxoid); listeria selective agar supplemented with SR0227E and yersinia selective agar supplemented with yersinia selective supplement were used as selective medium for the determination of coliform bacteria, E. coli O157:H7, Salmonella spp., L. monocytogens and $Y$. enterocolitica respectively.

After incubation of enumeration media at $37{ }^{\circ} \mathrm{C}$ for 24 to $48 \mathrm{~h}$ at least five presumptive colonies of Salmonella, E. coli O157:H7 and L. monocytogenes were confirmed with direct immunoassay test kit (Universal Health Watch, Columbia, MD, USA.). All experiments were repeated five times to confirm reproducibility. 

of Disinfectants in Reducing the Microbial Load

\subsection{Antibiotic Susceptibility of Isolated Pathogens from Tomato}

Susceptibility of isolated bacteria to different antimicrobial agents was determined in vitro according to Bauer-Kirby disc diffusion methods [10]. Commercially available antimicrobial discs (Oxoid Ltd., Basing stoke, Hants, UK) of ampicilin (AMP = $25 \mu \mathrm{g}$ ), amoxicillin (AML $=10 \mu \mathrm{g}$ ), azithromycin $(\mathrm{AZM}=15 \mu \mathrm{g})$, amikacin $(\mathrm{AK}=30 \mu \mathrm{g})$, aztronem $(\mathrm{ATM}=30 \mu \mathrm{g})$, cefrixone $(\mathrm{CRO}=30 \mu \mathrm{g})$, cefotaxime $(\mathrm{CTX}=30 \mu \mathrm{g})$, cefuroxime $(\mathrm{CXM}=30 \mu \mathrm{g})$, chloramphenicol $(\mathrm{C}=30 \mu \mathrm{g})$, cefepime $(\mathrm{FEP}=30 \mu \mathrm{g})$, cephalexin $(\mathrm{CL}=30 \mu \mathrm{g})$, clindamycin $(\mathrm{DA}=12 \mu \mathrm{g})$, doxycycline $(\mathrm{DO}=30 \mu \mathrm{g})$, erythromycin $(\mathrm{E}=50 \mu \mathrm{g})$, gentamycin $(\mathrm{CN}=10 \mu \mathrm{g})$, kanamycin $(\mathrm{K}=30 \mu \mathrm{g})$, levofloxacine ( $\mathrm{LEV}=5 \mu \mathrm{g})$, nitrofuran $(\mathrm{F}=300 \mu \mathrm{g})$, oxytetracycline $(\mathrm{OT}=30 \mu \mathrm{g})$, rifampicin $(\mathrm{RD}=5 \mu \mathrm{g})$, oxacillin $(\mathrm{OX}=1 \mu \mathrm{g})$, vancomycin $(\mathrm{VA}=30 \mu \mathrm{g})$, imipenem (IPM $=10 \mu \mathrm{g}$ ) and sulphamethoxozole $(\mathrm{SXT}=25 \mu \mathrm{g})$ were used to detect the zone of inhibition around the antibiotic disc.

\subsection{Plasmid DNA Extraction}

Plasmid DNA was extracted from the fresh tomato isolates grown in Luria Broth (LB) medium and incubated at $37^{\circ} \mathrm{C}$ overnight with mild shaking $(180 \times$ g) [11]. After incubation, $1 \mathrm{~mL}$ of the culture was taken and centrifuged $(16,000 \times \mathrm{g} ; 30 \mathrm{~s})$ at $4{ }^{\circ} \mathrm{C}$. The supernatant was removed and the pellet was resuspended in $150 \mu \mathrm{L}$ of Tris-EDTA buffer $10 \mathrm{mM}$ Tris chloride ( $\mathrm{pH}$ 8), $1 \mathrm{mM}$ EDTA (pH 8) solution by vigorous vortexing. Two hundred microliter of $\mathrm{NaOH}-\mathrm{SDS}(0.2 \mathrm{M} \mathrm{NaOH}, 1 \% \mathrm{SDS})$ solution and 150 $\mu \mathrm{L}$ of $3 \mathrm{M}$ potassium acetate ( $\mathrm{pH} 4.8$ ) were then added and vortexed for $10 \mathrm{~s}$. The content was centrifuged $(16,000 \times \mathrm{g} ; 5 \mathrm{~min})$ again at $4{ }^{\circ} \mathrm{C}$ and the supernatant was precipitated with $600 \mu \mathrm{L}$ of ice cold ethanol [11].

A portion $(15 \mu \mathrm{L})$ of plasmid DNA was loaded on to a $1.0 \%$ agarose gel containing $0.5 \mu \mathrm{g} \mathrm{mL}-1$ ethidium bromide and electrophoresed in TBE (Tris-Boric acid-EDTA) buffer. The plasmid DNA were visualized by placing the gel on a UV $(300 \mathrm{~nm})$ transilluminator and recorded using the digital documentation imaging system (model universal Hood II; BIO-RAD Laboratories, Hercules, CA, USA).

\subsection{Statistical Analysis}

All trials were replicated five times. Reported plate count data represent the mean values obtained from five individual trials, with each of these values being obtained from duplicated samples. Data were subjected to analysis of variance using the Microsoft Excel program (Redmond, Washington DC, USA.). Significant differences in plate count data were established by the least-significant difference at the $5 \%$ level of significance.

\section{Results and Discussions}

3.1 The Average Bacterial Load, Presence of Pathogens, and Washing with Sanitizers of Tomato Samples Collected from Different Markets

The averaged viable bacterial load in tomato samples $(n=10)$ was $>5.0 \log$ CFU/g purchased from three different local markets in Dhaka city. No significant difference in viable count was observed between three markets of Dhaka city. It is likely that the tomato samples were produced in same area and distributed to different markets.

Total coliform count in tomato samples from three different local markets was between 4.9-5.2 log $\mathrm{CFU} / \mathrm{g}$ (Table 1). The high microbial load observed in tomatoes of three different local markets in this study indicates the unhygienic conditions of the place where the tomatoes was prepared and the unhygienic storage conditions and temperatures.

E. coli was dominant in all the three market samples indicating possible sewage contamination. The highest $E$. coli population of $4.48 \pm 0.30 \mathrm{log}$ $\mathrm{CFU} / \mathrm{g}$ was recorded in Jatrabari markets (Table 2). Although higher number of presumptive Salmonella population, Listeria spp. and Yersinia spp. were detected from the respective selective media in the tested 
Table 1 Total viable bacteria and coliform count of tomato samples collected from three different market of Dhaka city.

\begin{tabular}{lll}
\hline \multirow{2}{*}{ Sampling site } & \multicolumn{2}{c}{ Population $\left(\log\right.$ CFU/g) ${ }^{\mathrm{a}}$} \\
\cline { 2 - 3 } & $\begin{array}{l}\text { Total viable } \\
\text { bacterial count }\end{array}$ & $\begin{array}{l}\text { Total coliform } \\
\text { count }\end{array}$ \\
\hline Jatrabari market & $5.7 \pm 0.3$ & $5.2 \pm 0.04$ \\
Anandabazar market & $5.3 \pm 0.1$ & $4.9 \pm 0.1$ \\
Mirpur market & $5.6 \pm 0.04$ & $5.2 \pm 0.04$ \\
\hline
\end{tabular}

${ }^{a} . \mathrm{n}=3$ for each data, count $=$ average of " $\Sigma \mathrm{n} " \pm \mathrm{SD}$.

Table 2 Prevalence of pathogens in tomato samples collected from three different market of Dhaka city.

\begin{tabular}{llll}
\hline \multirow{2}{*}{$\begin{array}{l}\text { Pathogen of } \\
\text { interest }\end{array}$} & \multicolumn{3}{c}{ Population $(\log$ CFU/g) } \\
\cline { 2 - 4 } & $\begin{array}{l}\text { Jatrabari } \\
\text { market }\end{array}$ & $\begin{array}{l}\text { Anandabazar } \\
\text { market }\end{array}$ & $\begin{array}{l}\text { Mirpur } \\
\text { market }\end{array}$ \\
\hline Salmonella spp. & $4.5 \pm 0.5$ & $3.3 \pm 0.1$ & $3.9 \pm 0.3$ \\
Listeria spp. & $4.4 \pm 0.1$ & $3.7 \pm 0.1$ & $4.1 \pm 0.1$ \\
Y. enterocolitica & $2.9 \pm 0.4$ & $2.7 \pm 0.3$ & $2.8 \pm 0.5$ \\
E. coli & $4.5 \pm 0.3$ & $3.9 \pm 0.7$ & $3.8 \pm 0.1$ \\
\hline${ }^{\mathrm{a}} \mathrm{n}=3$ for each data, count $=$ average of " $\Sigma \mathrm{n}$ " \pm SD.
\end{tabular}

tomato samples from three different local markets (Table 2). However, pathogenic L. monocytogenes and $Y$. enterocolitica were negative in confirmatory study. Salmonella was predominant in all the tested samples. Therefore, eating raw tomatoes from the local markets is of public health significance. Washing with sanitizers or other means of processing steps is required to reduce the risk of eating tomatoes contaminated with Salmonella.

The control of fresh produce-pathogenic microorganisms with various chemical disinfectants has been widely applied $[12,13]$. In this study, ASC and chlorinated water were used as washing solutions and both showed effectiveness in reducing total bacterial load more than $2.0 \log \mathrm{CFU} / \mathrm{g}$. Washing only with tap water was unable to reduce the bacterial number significantly as compared to the untreated samples. Interestingly, sanitizers wash were unable to reduce viable bacteria count of Jatrabari market tomato samples (Table 3). Chlorinated water wash showed maximum reduction of total viable bacteria irrespective of the sample tested from different markets of Dhaka city. ASC has been widely used for better sanitizing effect than chlorinated water, however, in this experiment ASC showed less effective than chlorinated water. This might be due to the variation of samples and environmental conditions of the samples or the sanitizing samples losses its activity while it comes in contact with organic materials on the tomato surfaces.

Prevalence of four foodborne pathogens Salmonella, E. coli O157:H7, Listeria spp. and Y. enterocolitica were recorded from three different market samples (Jatrabari $>$ Mirpur $\equiv$ Anadabazar). Washing with 200 ppm chlorinated water showed inactivation of all these pathogens, and no viable bacteria was found for Anandabazar and Mirpur markets samples after treating with chlorinated water.

Table 3 Effectiveness of sanitizers on total viable bacterial count and on selected pathogens in tomato samples collected from three different markets of Dhaka city.

\begin{tabular}{lllllll}
\hline \multirow{2}{*}{ Treatment sampling site } & \multicolumn{5}{c}{ Population $\left(\log\right.$ CFU/g) ${ }^{\mathrm{a}}$} \\
\cline { 3 - 7 } & Jotal viable count & Salmonella spp. & E. coli & Listeria spp. & Yersinia spp. \\
\hline \multirow{3}{*}{ Untreated } & Anabari market & $5.7 \pm 0.3$ & $4.5 \pm 0.5$ & $4.5 \pm 0.3$ & $4.4 \pm 0.1$ & $2.7 \pm 0.3$ \\
& Mirpur market & $5.6 \pm 0.04$ & $3.3 \pm 0.1$ & $3.5 \pm 0.7$ & $3.7 \pm 0.1$ & $2.0 \pm 0.2$ \\
& Jatrabari market & $5.3 \pm 0.1$ & $3.9 \pm 0.3$ & $3.8 \pm 0.1$ & $4.1 \pm 0.1$ & $3.5 \pm 0.1$ \\
\hline \multirow{3}{*}{ Tap water } & Anandabazar market & $4.9 \pm 0.3$ & $3.2 \pm 0.1$ & $8.5 \pm 0.1$ & $4.5 \pm 0.1$ & $1.5 \pm 0.2$ \\
& Mirpur market & $4.4 \pm 0.1$ & $3.7 \pm 0.1$ & $7.1 \pm 0.7$ & $3.7 \pm 0.1$ & $\leq 1.0$ \\
& Jatrabari market & $4.8 \pm 0.5$ & $3.1 \pm 0.1$ & $4.5 \pm 0.2$ & $2.8 \pm 0.2$ & $\leq 1.0$ \\
\multirow{2}{*}{ Chlorinated } & Anandabazar market & $2.8 \pm 0.01$ & $\leq .5 \pm 0.1$ & $3.1 \pm 0.03$ & $2.7 \pm 0.03$ & $\leq 1.0$ \\
& Mirpur market & $1.5 \pm 0.1$ & $\leq 1.0$ & $\leq 1.0$ & $\leq 1.0$ & $\leq 1.0$ \\
\hline \multirow{2}{*}{ Acidified } & Jatrabari market & $5.0 \pm 0.3$ & $2.9 \pm 0.3$ & $6.9 \pm 0.2$ & $2.9 \pm 0.2$ & $2.8 \pm 0.3$ \\
& Anandabazar market & $2.7 \pm 0.2$ & $\leq 1.0$ & $3.7 \pm 0.5$ & $3.0 \pm 0.4$ & $\leq 1.0$ \\
\hline
\end{tabular}

$\mathrm{n}=3$ for each data, count $=$ average of " $\mathrm{n}$ " \pm SD. 
In contrast, ASC was able to reduce $\leq 2.0 \mathrm{log}$ $\mathrm{CFU} / \mathrm{g}$ of these pathogens (Table 3). Interestingly, chlorinated water reduced $\leq 2.0 \mathrm{log} \mathrm{CFU} / \mathrm{g}$ of the pathogens from three different markets, however, ASC showed less or no effect for Jatrabari samples. This might be due to variation of viable bacterial load from sample to sample, from tomato to tomato (Table 1). For washing experiment, one tomato was used for a single washing, so, it was not possible to see the effect of bacterial population with same sanitizer of same sample. In case of Jatrabari samples, the viable bacterial count and the pathogenic bacteria count was high or was heavily contaminated. As this is a wholesale market, the samples coming from distant places were mixed and some samples were coming directly from the field, or farmers. Moreover, Jatrabari samples may be more subjected to chemical treatment, which might be responsible for low effectiveness of sanitizer and occurrences of high microbial load as compared to Anandabazar and Mirpur markets. Pathogenic E. coli and Listeria spp. was recorded the highest from Jatrabari market $4.5 \pm 0.3$ and $4.4 \pm 0.1$ $\log \mathrm{CFU} / \mathrm{g}$, respectively.

Washing with $200 \mathrm{ppm}$ chlorinated water could successfully eliminate all these tested pathogen from all the samples. The variation of these results might be due to the adaptation of pathogens in environment and susceptibility to sanitizers. Moreover, high resistance to sanitizers of Jatrabari sample bacteria/pathogens could be due to microbial internalization and/or biofilm formation occurring between the times of contamination and washing may be contributing factors. If pathogen contamination of produce occurs at pre-harvest or during harvest, sufficient time may elapse before washing to enable these protective factors reduce the efficacy of the sanitizers treatments $[14,15]$.

\subsection{Antibiotic Resistance and Plasmid Profiles in Bacteria Isolated From Tomato Samples}

The antibiotic response of the strains revealed that almost all of the isolates were uniformly resistant to rifampicin, erythromycin, clindamycin and oxacillin (100\%), vancomycin (93\%), amoxicillin (87\%), whereas $60 \%$ of the isolates were found to be resistant to ampicillin and cephalexin (Table 4, Fig. 1). Apart from this, almost all of the isolates tested were found to be uniformly susceptible to levofloxacin and imipenem (100\%), whereas $93 \%$ of the isolates were found to be sensitive to chloramphenicol, sulphamethoxazole and amikacin, $87 \%$ of the isolates were found to be sensitive to cefriaxone, cefotaxime and cfepime, whereas $80 \%$ of the isolates were found to be sensitive to gentamycin and aztreonam. These experimental results also suggested that multidrug resistance (MDR) to environmental bacteria was increasing and almost every bacterium was resistant to more than one antibiotic.

Plasmid profile of the 10 isolates showed that almost all isolates contained plasmid. Isolate $5 \mathrm{had}$ almost $14 \mathrm{~kb}$ plasmid and isolates 1, 2, 3 and $10 \mathrm{had}$ approximately 10 to $11 \mathrm{~kb}$ plasmid and almost all isolates contained multicopy plasmids (Fig. 2). Kalantar et al. [16] studied the presence of plasmids of molecular sizes ranging from $1.4 \mathrm{~kb}$ to $4.5 \mathrm{~kb}$ among the acute diarrhea causing $E$. coli isolates showing resistance to ampicillin (A), chloramphenicol (C) and tetracycline $(\mathrm{T})$, and stated that these resistances are plasmid mediated. However, the authors did not carry out conjugation or plasmid curing experiments in order to establish the involvement of the plasmid in carrying ACT-resistance among the isolates studied. Data on the prevalence and types of antibiotic resistance in microorganisms isolated from fresh produce may help explain the role of foods in the transmission of antibiotic-resistant strains to human populations.

\section{Conclusions}

In conclusion, the result of this study demonstrated that the tomato samples collected from local markets were heavily contaminated with multidrug resistant 

of Disinfectants in Reducing the Microbial Load

Table 4 Antibiotic sensitivity pattern of 15 isolates against 24 commonly used antibiotics.

\begin{tabular}{|c|c|c|c|c|}
\hline $\begin{array}{l}\text { Isolate } \\
\text { No. }\end{array}$ & $\begin{array}{l}\text { Suspected } \\
\text { microorganism }\end{array}$ & Resistant & Sensitive & Intermediate \\
\hline 1 & Salmonella spp. & AML,CL, DA, E, RD,OX,VA & \multicolumn{2}{|c|}{$\begin{array}{l}\text { AMP, AZM, AK, ATM, CRO,CTX, C, FEP, DO,CN, CXM, K, F } \\
\text { LEV,OT, IPM, SXT }\end{array}$} \\
\hline 2 & Salmonella spp. & AMP, AML, DA, E, RD,OX,VA & \multicolumn{2}{|c|}{$\begin{array}{l}\text { AZM, AK, ATM,CRO,CTX, C, FEP, DO, CN, LEV, OT, CXM, CL } \\
\text { IPM, SXT, K, F }\end{array}$} \\
\hline 3 & Salmonella spp. & AML, DA, E, RD,OX,VA & \multicolumn{2}{|c|}{$\begin{array}{l}\text { AMP, AZM, AK, ATM, CRO, CTX, C, FEP, DO, CN, LEV, CL } \\
\text { OT, IPM, SXT, K, F, CXM }\end{array}$} \\
\hline 4 & Salmonella spp. & $\begin{array}{l}\text { AMP, AML, ATM, CRO, } \\
\text { CTX, CXM, FEP, DA, E, K, F, OT, } \\
\text { RD, OX, VA }\end{array}$ & IPM, SXT, LEV, CN, DO,C, AK, AZM & $\mathrm{CL}$ \\
\hline 5 & Salmonella spp. & $\begin{array}{l}\text { DA, E, RD,OX,VA ,OT, } \\
\text { CL, AMP, AML }\end{array}$ & SXT, C, AK, K, IPM, CN, ATM, CRO, CTX, CXM, FEP & F, DO,CXM, AZM \\
\hline 6 & Salmonella spp. & $\begin{array}{l}\text { AMP, AML, CL, DA, DO, E, OT, } \\
\text { RD ,OX, VA }\end{array}$ & AK, ATM, CRO, CTX, C, FEP, CN, K, LEV, IPM, SXT & CXM, AZM, F \\
\hline 7 & Salmonella spp. & $\begin{array}{l}\text { AMP, AML, CL, DA, E,OT,RD, } \\
\text { OX,VA }\end{array}$ & $\begin{array}{l}\text { AK, ATM,CRO,CTX,C, FEP,CN, } \\
\text { K, LEV, IPM, SXT }\end{array}$ & AZM, CXM, F, DO \\
\hline 8 & E. coli & AMP, AML, DA, E, RD, OX,VA & AK, ATM, CRO, C, CTX, FEP, DO, K, LEV,OT, IMP, SXT & $\mathrm{AZM}, \mathrm{CXM}, \mathrm{CL}, \mathrm{CN}, \mathrm{F}$ \\
\hline 9 & E. coli & $\begin{array}{l}\text { AMP,AML,CL,DA,DO,E,F,RD,OX,V } \\
\text { A }\end{array}$ & $\begin{array}{l}\text { AK, ATM,CRO,CTX, FEP,CN,K, } \\
\text { LEV, OT, IPM, SXT }\end{array}$ & AZM, CXM, C \\
\hline 10 & E. coli & $\begin{array}{l}\text { AMP, AML, CL, DA, DO, E, RD, } \\
\text { OX,VA }\end{array}$ & AZM, AK, ATM,CRO,CTX, FEP, K, LEV, OT, IPM, SXT & $\mathrm{CXM}, \mathrm{C}, \mathrm{CN}, \mathrm{F}$ \\
\hline 11 & E. coli & AML, DA, E, RD,OX,VA & \multicolumn{2}{|c|}{$\begin{array}{l}\text { AMP, AZM, AK, ATM, CRO, CTX,C, FEP, DO, LEV,OT, CXM, CL, CN, K, F } \\
\text { IPM, SXT }\end{array}$} \\
\hline 12 & E. coli & $\begin{array}{l}\text { AMP, AML, ATM, CXM, } \\
\text { CL, DA, E, F, RD, OX,VA }\end{array}$ & AZM, AK, CRO, C, FEP, DO, K, LEV, OT, IPM & CTX, CN, SXT \\
\hline 13 & E. coli & $\begin{array}{l}\text { ATM, CTX, CXM, FEP, CL, DA, E, } \\
\text { RD, VA, OX }\end{array}$ & $\begin{array}{l}\text { AMP,AML,AZM,C,DO,CN, LEV, } \\
\text { F,OT, IPM, SXT }\end{array}$ & $\mathrm{AK}, \mathrm{CRO}, \mathrm{K}$ \\
\hline 14 & E. coli & AML, CL, DA, DO, E,OT,RD,OX,VA & \multicolumn{2}{|c|}{$\begin{array}{l}\text { AMP, AK, ATM, CRO, CTX, CXM, FEP, C, CN, K, LEV, AZM, F } \\
\text { IPM, SXT }\end{array}$} \\
\hline 15 & E. coli & $\begin{array}{l}\text { AMP, AML, CL, DA, DO,E, OT, RD, } \\
\text { OX, VA }\end{array}$ & AK, ATM, CRO, CTX, FEP, C, CN, K, LEV, IPM, SXT & $\mathrm{AZM}, \mathrm{CXM}, \mathrm{F}$ \\
\hline
\end{tabular}

Amp = Ampicillin, AML $=$ Amoxicillin, AZM = Azithromycin, AK = Amikacin, ATM = Aztreonam, CRO = Cefriaxone, $\mathrm{CTX}=$ Cefotaxime, $\mathrm{CXM}=$ Cefuroxime, $\mathrm{C}=$ Chloramphenicol, $\mathrm{FEP}=\mathrm{Cfepime}, \mathrm{CL}=$ Cephalexin, $\mathrm{DA}=\mathrm{Clindamycin}, \mathrm{DO}=\mathrm{Doxycycline}$, $\mathrm{E}=$ Erythromycin, $\mathrm{CN}=$ Gentamycin, $\mathrm{K}=$ Kanamycin, $\mathrm{LEV}=$ Levofloxacin, $\mathrm{F}=$ Nitrfuran, $\mathrm{OT}=$ Oxytetracycline, $\mathrm{RD}=\mathrm{Rifampicin}$, $\mathrm{OX}=$ Oxacillin, $\mathrm{VA}=$ Vancomycin, IPM $=$ Imipenem and SXT $=$ Sulphamethoxazole.

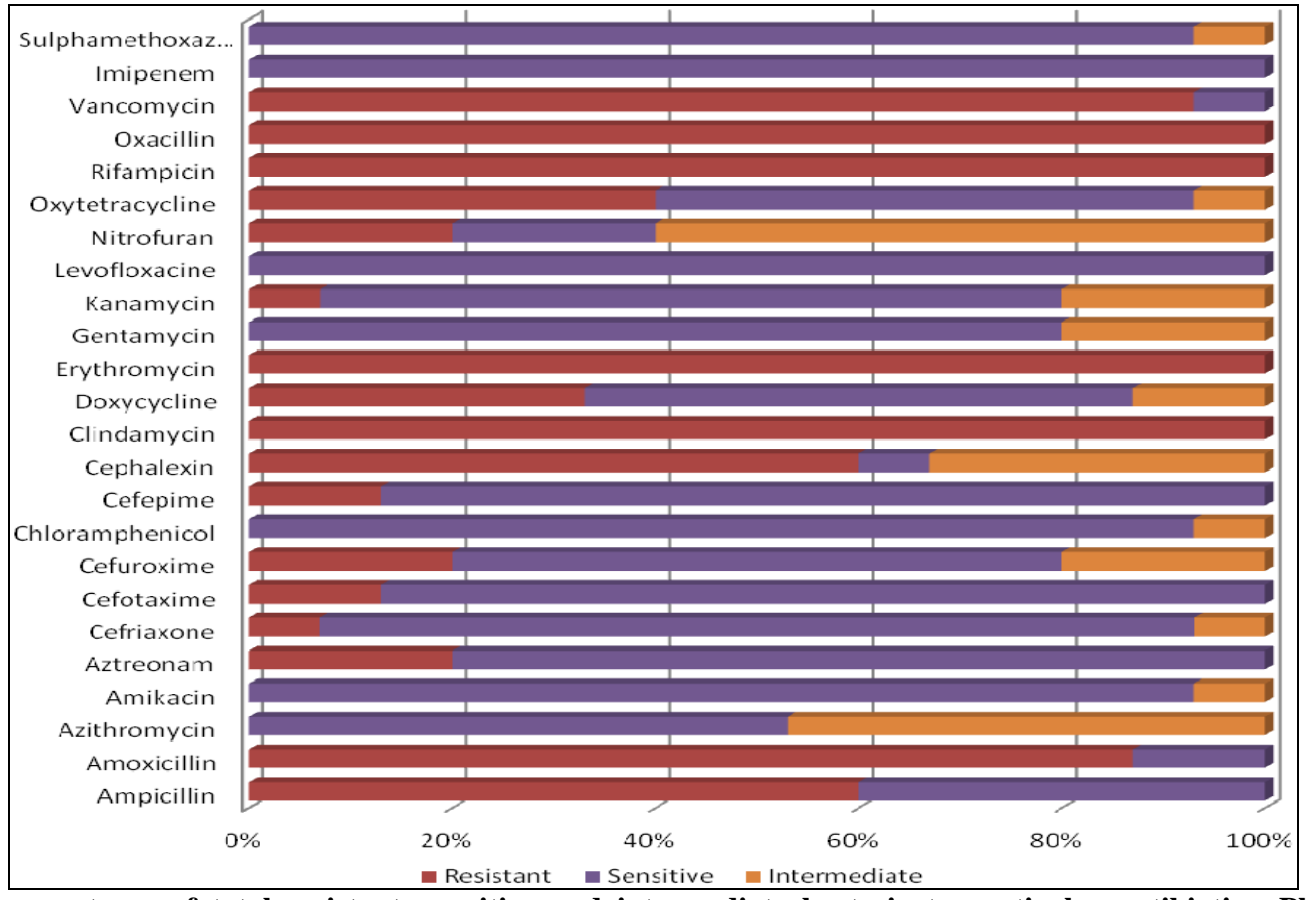

Fig. 1 The percentages of total resistant, sensitive and intermediate bacteria to particular antibiotics. Plasmid profile analysis. 




Fig. 2 Agarose gel electrophoresis of plasmid DNA of resistant isolates. E. coli PDK-9 was used as a marker in last lane (Lane 12); Lane 1 (10 Kb marker); Lanes 1 to 11 antibiotic resistant samples of Salmonella spp. and E. coli.

bacteria and is of special concern for human consumption. Antibiotic sensitivity pattern, isolated strains and corresponding plasmid profiling indicated a correlation of plasmid mediated multidrug resistance (MDR) of these environmental bacteria. Washing with ASC and 200 ppm chlorinated water was able to reduce $\leq 2.0 \log \mathrm{CFU} / \mathrm{g}$ of natural microflora and coliform bacteria and chlorinated water was able to reduce other pathogens up to undetectable level. Therefore, washing of tomato with $200 \mathrm{ppm}$ chlorinated water could be useful in reducing the pathogen populations on tomatoes.

\section{Acknowledgment}

This research work was supported by Ministry of Science, Information, \& Technology, Bangladesh, during FY 2010-11, and its Follow-up Project in 2011-2013. Authors expressed their sincere gratitude to the authorities of the Center for Advanced Research in Sciences (CARS) for providing laboratory facilities and logistic supports to carry out this investigation.

\section{References}

[1] FAO, A Millennium Free from Hunger, Brochure Prepared for World Food Day, Oct. 16, 2000, p. 28.
[2] CDC, National Antimicrobial Resistance Monitoring System (NARMS) Frequently Asked Questions (FAQ) about Antibiotic Resistance-Why is Antibiotic Resistance a Food Safety Problem?, Cdc. Gov., 2005, http://www.cdc.gov/narms/faq_pages/5.htm. (accessed January, 2011)

[3] FDA, FDA Statement, FDA investigates certain Roma tomatoes as source of foodborne illness outbreaks in Pennsylvania, Ohio, and Mid-Atlantic states, FDA Press Release [Online], July 16, 2004, http://www.fda.gov/oc/po/firmrecalls/archive2004.html. (accessed Oct. 19, 2005)

[4] P. Srikantiah, B. Bodager, B. Toth, T. Kass-Hout, R. Hammond, S. Stenzel, et al., Web based investigation of salmonellosis outbreak, Emerg. Infect. Dis. 11 (4) (2005) 610-612.

[5] L.R. Beuchat, J.H. Ryu, Produce handling and processing practices, Emerg. Infect. Dis. 3 (1997) 459-465.

[6] Klonsky, E. coli in spinach, foodborne illnesses, and expectation about food safety, Agricultural and Resource Economics Update 10 (2006) 1-4.

[7] L.R. Beuchat, L.J. Harris, T.E. Ward, T.M. Kajs, Development of a proposed standard method for assessing the efficacy of fresh produce sanitizers, J. Food. Prot. 64 (2001) 1103-1084.

[8] L.R. Beuchat, B.V. Nail, B.B. Adler, M.R.S. Clavero, Efficacy of spray application of chlorinated water in killing pathogenic bacteria on raw apples, tomatoes, and lettuce, J. Food Prot. 61 (1998) 1305-1311.

[9] Anonymous, Acidified sodium chlorite solutions, 21 CFR 173.325, Code of Federal Regulations, Office of the Federal Register, U.S. Government Printing Office, 
Washington, DC, 1999.

[10] A.W. Bauer, W.M. Kirby, J.C. Sheris, M. Turck, Antibiotic susceptibility testing by a standardized single disc method, Am. J. Clin. Pathol. 45 (1996) 149-158.

[11] H.C. Birnboim, J. Doly, A rapid alkaline extraction procedure for screening recombinant plasmid DNA, Nucleic Acids Res. 7 (1979) 1513-1523.

[12] FDA, FDA Survey of Imported Fresh Produce, US Food and Drug Administration, 2001.

[13] W.N. Wade, A.J. Scouten, K.H. McWatters, R.L. Wick, A. Demirci, W.F. Fett, et al., Efficacy of ozone in killing Listeria monocytogenes on alfalfa seeds and sprouts and effects on sensory quality of sprouts, J. Food Prot. 66 (2003) 44-51.

[14] D.O. Ukuku, G.M. Sapers, Effect of sanitizer treatments on Salmonella stanley attached to the surface of cantaloupe and cell transfer to fresh-cut tissues during cutting practices, J. Food Prot. 64 (2001) 1286-1291.

[15] G.M. Sapers, D.M. Jones, Improved sanitizing treatments for fresh tomatoes, J. Food Sci. 71 (2006) M252-M256.

[16] E. Kalantar, F. Soheili, H, Salimi, D.M. Soltan, Frequency, antimicrobial susceptibility and plasmid profiles of Escherichia coli pathotypes obtained from children with acute diarrhea, Jundishapur J. Microbiol. 4 (2011) 23-28. 